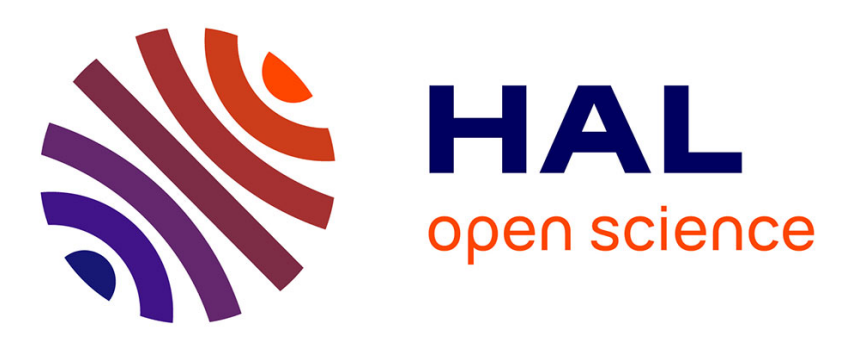

\title{
Will Sodium Layered Oxides Ever Be Competitive for Sodium Ion Battery Applications?
}

Sathiya Mariyappan, Qing Wang, Jean-marie Tarascon

\section{To cite this version:}

Sathiya Mariyappan, Qing Wang, Jean-marie Tarascon. Will Sodium Layered Oxides Ever Be Competitive for Sodium Ion Battery Applications?. Journal of The Electrochemical Society, 2018, 165 (16), pp.A3714-A3722. 10.1149/2.0201816jes . hal-01954629

\section{HAL Id: hal-01954629 \\ https://hal.sorbonne-universite.fr/hal-01954629}

Submitted on 13 Dec 2018

HAL is a multi-disciplinary open access archive for the deposit and dissemination of scientific research documents, whether they are published or not. The documents may come from teaching and research institutions in France or abroad, or from public or private research centers.
L'archive ouverte pluridisciplinaire HAL, est destinée au dépôt et à la diffusion de documents scientifiques de niveau recherche, publiés ou non, émanant des établissements d'enseignement et de recherche français ou étrangers, des laboratoires publics ou privés. 


\title{
Will Sodium Layered Oxides Ever Be Competitive for Sodium Ion Battery Applications?
}

\author{
Sathiya Mariyappan, ${ }^{1,2}$ Qing Wang, ${ }^{1,3}$ and Jean Marie Tarascon $\oplus^{1,2,3, z}$ \\ ${ }^{1}$ Chimie du Solide-Energie, UMR 8260, Collège de France, 75231 Paris Cedex 05, France \\ ${ }^{2}$ Réseau sur le Stockage Electrochimique de l'Energie (RS2E), FR CNRS 3459, France \\ ${ }^{3}$ Sorbonne Universités - UPMC Université Paris 06, 75005, Paris, France
}

\begin{abstract}
The Na-ion battery technology is rapidly developing as a possible alternative to Li-ion for massive electrochemical energy storage applications because of sustainability and cost reasons. Two types of technologies based either on sodium layered oxides $\mathrm{Na}_{\mathrm{x}} \mathrm{MO}_{2}(\mathrm{x}$ $\leq 1, \mathrm{M}=$ transition metal ion(s)) or on polyanionic compounds such as $\mathrm{Na}_{3} \mathrm{~V}_{2}\left(\mathrm{PO}_{4}\right)_{2} \mathrm{~F}_{3}$ as positive electrode and carbon as negative electrode are presently being pursued. Herein, we benchmark the performance of full Na-ion cells based on several sodium layered oxide materials against $\mathrm{Na}_{3} \mathrm{~V}_{2}\left(\mathrm{PO}_{4}\right)_{2} \mathrm{~F}_{3}$ /hard carbon cells. Although several studies report more attractive capacities for sodium layered oxides vs. Na metal $\left(\sim 200 \mathrm{mAh} \mathrm{g}^{-1}\right)$ than for polyanionic phases $\left(\sim 120 \mathrm{mAh} \mathrm{g}^{-1}\right)$, we find that such advantages are not maintained when assembling practical full Na-ion cells; the opposite of what is found for $\mathrm{Li}$-ion technology. The reasons for such a loss of supremacy of the layered oxides against polyanionic compounds are discussed in terms of materials structural stability and composition so as to identify fundamental challenges that impede their practical applications. Finally, a few perspectives are given to design better sodium layered oxide electrode materials that could outweigh the performance of today's stellar $\mathrm{Na}_{3} \mathrm{~V}_{2}\left(\mathrm{PO}_{4}\right)_{2} \mathrm{~F}_{3}$. (C) The Author(s) 2018. Published by ECS. This is an open access article distributed under the terms of the Creative Commons Attribution Non-Commercial No Derivatives 4.0 License (CC BY-NC-ND, http://creativecommons.org/licenses/by-nc-nd/4.0/), which permits non-commercial reuse, distribution, and reproduction in any medium, provided the original work is not changed in any way and is properly cited. For permission for commercial reuse, please email: oa @ electrochem.org. [DOI: 10.1149/2.0201816jes]
\end{abstract}

(cc) BY-NC-ND

Manuscript submitted October 5, 2018; revised manuscript received November 14, 2018. Published December 1, 2018.

Energy storage devices are one of the key components that we depend on in our everyday life. Because of their light weight and high energy density, Li-ion batteries (LIBs) are presently powering most of the portable electronics and are also on the verge to fully conquer the Electrical Vehicle (EV) market. ${ }^{1,2}$ Therefore, for mass storage associated to the use of renewable energies, there is a sore need for low cost batteries that utilize more sustainable materials. ${ }^{3,4}$ In this regard, sodium ion batteries (NIBs) that have similar redox chemistry as Li-ion ones, but rely on the use of abundant and low cost $\mathrm{Na}$ metal, are regaining great research interest. Such a blooming research has led over the last 5-6 years to a rapid increase in the discovery of attractive positive and negative electrode materials for making full $\mathrm{Na}$-ion cells. ${ }^{5}$ Materials-wise, there has not been real surprises since the identified Na-insertion candidates belong either to the layered oxides or to the polyanionic family, ${ }^{5-9}$ like for the Li-ion technology, with however fewer members because of the greater size of $\mathrm{Na}^{+}$as compared to $\mathrm{Li}^{+}$ that limits structural variances. ${ }^{10} \mathrm{~A}$ similar analogy can be drawn for the negative electrode since carbon, or intermetallic alloys can act as hosts for the reversible $\mathrm{Na}^{+}$uptake. ${ }^{11}$

Altogether, two types of Na-ion technologies using carbon as negative electrode material and either a layered oxide $\mathrm{Na}_{\mathrm{x}} \mathrm{MO}_{2}$ (where $\mathrm{x} \leq 1$ and $\mathrm{M}$ is transition metal ion(s)) or a polyanionic compound $\mathrm{Na}_{3} \mathrm{~V}_{2}\left(\mathrm{PO}_{4}\right)_{2} \mathrm{~F}_{3}$, denoted hereafter NVPF, as positive electrode material, have emerged and are presently being

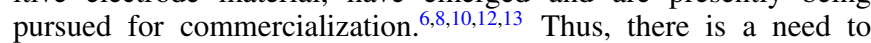
determine the performance-wise most attractive electrode material among them. Previous comparative studies have indicated that $\mathrm{Na}_{3} \mathrm{~V}_{2}\left(\mathrm{PO}_{4}\right)_{2} \mathrm{~F}_{3} /$ hard carbon (HC) cells could compete favorably with $\mathrm{Na}_{0.67} \mathrm{Fe}_{0.5} \mathrm{Mn}_{0.5} \mathrm{O}_{2} / \mathrm{HC}$ cells although the practical capacity of NVPF does not exceed $128 \mathrm{mAh} \mathrm{g}^{-1} .{ }^{14}$ The reasons are twofold, namely i) the large output voltage $(\sim 3.6 \mathrm{~V})$ for $\mathrm{NVPF} / \mathrm{HC}$ cells as compared to $\sim 2.6 \mathrm{~V}$ for $\mathrm{P} 2-\mathrm{Na}_{0.67} \mathrm{Fe}_{0.5} \mathrm{Mn}_{0.5} \mathrm{O}_{2} / \mathrm{HC}$ cells and ii) the feasibility to utilize $1 \mathrm{Na}^{+}$per vanadium in $\mathrm{NVPF}$ as opposed to only $\sim 0.5$ 0.6 per $3 \mathrm{~d}$-metal in $\mathrm{P} 2-\mathrm{Na}_{0.67} \mathrm{Fe}_{0.5} \mathrm{Mn}_{0.5} \mathrm{O}_{2}$ layered oxide. This gap in favor of the NVPF/HC system has recently become even greater with the feasibility of using the $3^{\text {rd }} \mathrm{Na}^{+}$ion from NVPF as a reservoir to compensate for the $\mathrm{Na}$ lost due to the SEI formation during the first cycle (Fig. S1). ${ }^{15}$

Meanwhile, the supremacy of NVPF against Na-layered oxides in full Na-ion cells was demonstrated exclusively for a single P2-type

${ }^{\mathrm{z}}$ E-mail: jean-marie.tarascon@ college-de-france.fr sodium layered oxide member while the sodium layered oxide family offers rich crystal chemistry with numerous members that can adopt either O3, O1, P2 or P3 crystal structures. ${ }^{16-18}$ These structures differ by the stacking of $\mathrm{MO}_{2}$ layers and the occupancy/environment of the $\mathrm{Na}$ sites. O-type phases (O3 and $\mathrm{O} 1)$, for instance have sodium in the octahedral sites, whereas P-type (P2 and P3) phases have sodium in the prismatic sites. ${ }^{16}$ Moreover, their respective chemical stability depends on the sodium stoichiometry (x) and the nature of transition metal ion(s) involved. This results in the existence of a wide panel of Na-layered oxides that offer specific energy ranging from 400$600 \mathrm{Wh} \mathrm{kg}^{-1}$ in Na-half cells. These materials also differ in their redox processes enlisting numerous Na-driven phase transitions that affect their cycling performances. ${ }^{7}$ So, application-wise the burning question is to determine, which of these layered oxide is presently the best for full Na-ions cells?

To answer this question, we embarked on a comparative performance survey of various sodium layered oxide representatives that we have synthesized and studied for their electrochemical performances in half and full Na-ion cells and benchmarked against NVPF. We found that none of the state of the art Na-based layered oxides, reported to give large capacities in Na-half cells, could compete either in specific energy or in cyclability with NVPF in full Na-ion cells. Due to the fact that these performance limitations are related to structural issues, we have exploited a new material design approach based on iono-covalence considerations of the chemical substituents to develop novel layered oxides with enhanced structural stability and cycling performances.

\section{Experimental}

All the layered oxide materials reported herein were synthesized in-house by solid state synthesis. Stoichiometric amounts of the required transition metal oxide precursors or the co-precipitated transition metal carbonates were ball milled with $\mathrm{Na}_{2} \mathrm{CO}_{3}$ and heated at the required temperature prior to being quenched or slow cooled to room temperature. The detailed synthesis protocol for each material is given in supplementary information. Once recovered, the resulting powders were stored in an argon filled glove box prior to being analyzed for phase purity by X-ray diffraction analysis using a Bruker $\mathrm{d} 8$ diffractometer with $\mathrm{Cu} \mathrm{K}_{\alpha}$ radiation. The reactivity of the synthesized sodium layered oxides were tested by placing a part of the sample in a desiccator with controlled humidity of $\mathrm{RH} \sim 55 \%$. The humidity 
was controlled using a saturated solution of $\mathrm{Mg}\left(\mathrm{NO}_{3}\right)_{2}$ and the XRD pattern of the samples were measured after $24 \mathrm{~h}$ of storage at $55 \% \mathrm{RH}$

For electrochemical characterizations, the positive electrode composites were made by ball milling the prepared $\mathrm{Na}$-based phases with $15 \%$ super $\mathrm{P}$ carbon black for 30 minutes using a ball to powder material weight ratio of 23 . The resulting loose powders were tested in sodium half cells (Swagelok-type) against metallic sodium and in full Na-ion cells (coin-type CR2032) against a hard carbon electrode coated on aluminum foil with a $\sim 5.5 \mathrm{mg} / \mathrm{cm}^{2}$ loading. A solution of $1 \mathrm{M} \mathrm{NaPF}_{6}$ (stella chemifa) dissolved in propylene carbonate was used as electrolyte for both types of cells. For full Na-ion cells relying on the selected Na-based layered oxides, the mass balancing of the positive to negative material was done by equalizing the positive and negative material's practical capacity and having $4 \%$ (with respect to the practical capacity of positive electrode) excess of negative electrode to avoid sodium plating during cycling.

The assembled half and full cells were cycled galvanostatically at $\mathrm{C} / 10$ and $\mathrm{C} / 20$ respectively with $1 \mathrm{C}$ being the current to remove one sodium in 1 hour. The specific capacities were calculated from the weight of active material in the positive electrode, while specific energies were deduced by considering the total weight of positive and negative active material unless otherwise mentioned, for meaningful comparison. Only results that have been duplicated at least twice are reported. The tests for analyzing power rate capabilities were conducted in sodium half cells by collecting signature curves as follows. The cell was charged to $4.5 \mathrm{~V}$ at $\mathrm{C} / 10$ and then discharged back to $1.5 \mathrm{~V}$ by applying successive rates $5 \mathrm{C}, 2 \mathrm{C}, 1 \mathrm{C}, \mathrm{C} / 2$ etc to $\mathrm{C} / 20$, with a resting period of $10 \mathrm{~h}$ between each rate sequence.

Single-phased NVPF powders for benchmarking, made via a twostep ceramic process ${ }^{19}$ were used after mixing with $15 \%$ conductive carbon. The mass balancing of the NVPF to HC material for full cell assembly was done similarly to the sodium layered oxides by equalizing their practical capacity $\left(128 \mathrm{mAh} \mathrm{g}^{-1}\right.$ for NVPF and $300 \mathrm{mAh} \mathrm{g}^{-1}$ for hard carbon) and having $4 \%$ excess of hard carbon.
Cycling conditions for full NVPF/HC Na-ion cells were set, in light of our recent studies, to achieve the optimal performance in terms of specific energy and cycle life (Fig. S1). ${ }^{15}$ More specifically, NVPF/HC cells were first charged to $4.8 \mathrm{~V}$ in the first cycle to remove $2.35 \mathrm{Na}$ from the structure and then cycled over the voltage window of 2 to 4.3 $\mathrm{V}$ (Fig. S1). It is worth mentioning that for comparative purposes, the NVPF composite electrodes used in the present study consists of loose powders as opposed to a coated film electrodes used in our previous studies (Fig. S2). ${ }^{15}$

\section{Results and Discussion}

Selecting the representative sodium layered oxides.-Ten samples were selected for our study (see Table I). Firstly, they enlist Na-based layered oxides for which key performance values such as capacity, redox voltage, stability of the pristine phase to moisture/air and cycle-life were altogether reported in the literature. ${ }^{7,8}$ Secondly, we also considered layered oxides showing either anionic redox activity or enhanced capacity due to the sacrificial salt strategy. ${ }^{20,21}$ The nature and abundancy of the transition metals constituting layered oxides was also another criterion of choice hence the presence of numerous compounds in our selected list based on sustainable and cheap transition metal ions $\left(\mathrm{Fe}^{3+}, \mathrm{Cu}^{2+}, \mathrm{Mn}^{4+}, \mathrm{Ni}^{2+}\right.$, etc). Lastly, structuralwise we limit ourselves to materials showing exclusively $\mathrm{O} 3$ and $\mathrm{P} 2$ structures while disregarding the $\mathrm{O} 1$ and $\mathrm{P} 3$ materials.

The reason for such a choice is as follows. We chose $\mathrm{O} 3 \mathrm{NaMO}_{2}$ phases that are structurally identical to $\mathrm{Li}$ phases $\left(\mathrm{LiCoO}_{2}\right)$ which are at the heart of today's commercial Li-ion batteries, and therefore should lead to a similar alkali ion insertion mechanism. In contrast, the $\mathrm{O} 1$ phase $\left(\mathrm{NaMnO}_{2}, \mathrm{NaNiO}_{2}\right.$ and derivatives) differs from the $\mathrm{O} 3$ phase by having a monoclinic distortion due to Jahn Teller $\mathrm{Ni}^{3+} / \mathrm{Mn}^{3+}$ ion and it undergoes numerous Na-driven structural transitions upon cycling that penalize their capacity retention. ${ }^{22}$ Turning to the P3 $\mathrm{Na}_{\mathrm{x}} \mathrm{MO}_{2}$ phases, they were shown to stabilize with lower sodium

Table I. List of selected sodium layered oxide materials for the present study, with their reported capacities and the reasoning for the selection.

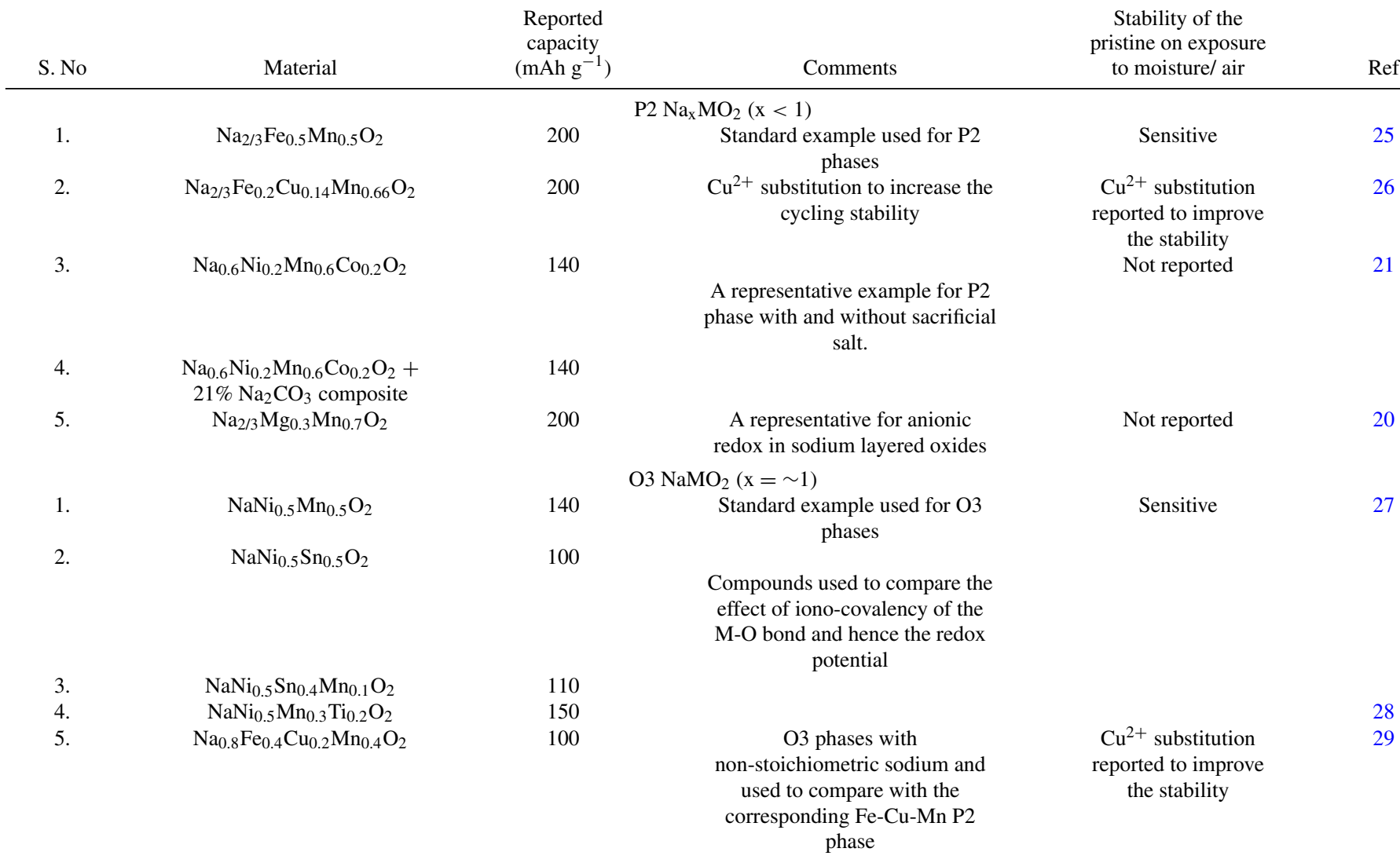




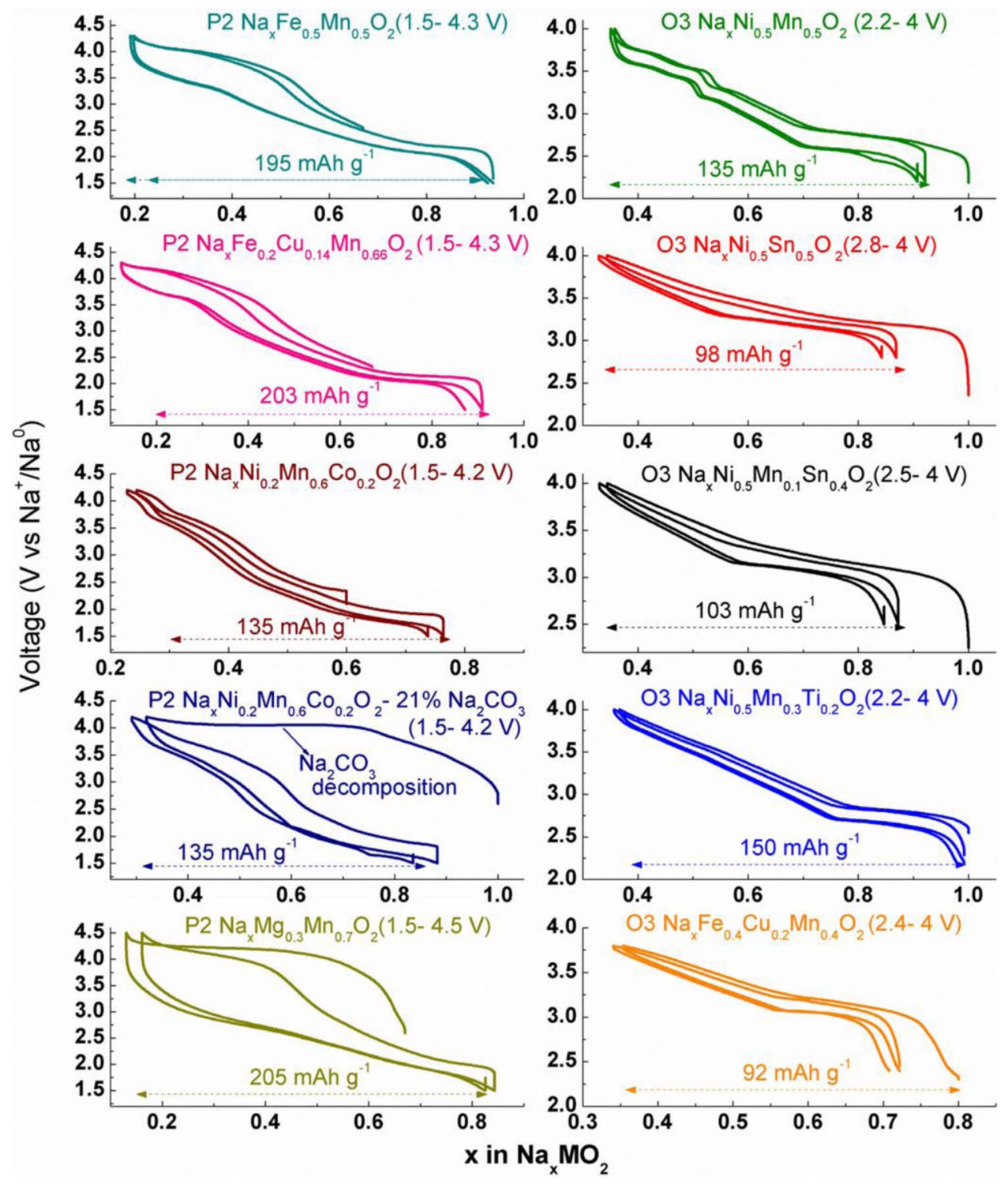

Figure 1. Voltage vs composition profile plots of the studied sodium layered oxide materials (left) $\mathrm{P} 2 \mathrm{Na}_{\mathrm{x}} \mathrm{MO}_{2}$ and (right) $\mathrm{O} 3 \mathrm{Na}_{\mathrm{x}} \mathrm{MO}_{2}$. The materials were tested in sodium half cells using metallic sodium as negative electrode. The cells were cycled galvanostatically at $\mathrm{C} / 10$ rate. The voltage window used for each material is indicated in their corresponding cycling profile plot. The long plateau observed at $4 \mathrm{~V}$ in the first charge of the P2 $\mathrm{Na}_{0.6} \mathrm{Ni}_{0.2} \mathrm{Mn}_{0.6} \mathrm{Co}_{0.2} \mathrm{O}_{2}+21 \% \mathrm{Na}_{2} \mathrm{CO}_{3}$ composite is due to the irreversible decomposition of $\mathrm{Na}_{2} \mathrm{CO}_{3}$. For calculation purposes, the total sodium in the composite $\mathrm{P} 2 \mathrm{Na}_{0.6} \mathrm{Ni}_{0.2} \mathrm{Mn}_{0.6} \mathrm{Co}_{0.2} \mathrm{O}_{2}+21 \% \mathrm{Na}_{2} \mathrm{CO}_{3}$ is used in the $\mathrm{x}$-axis; hence the starting sodium stoichiometry is mentioned as 1 , however the actual composition is $\mathrm{Na}_{0.6} \mathrm{Ni}_{0.2} \mathrm{Mn}_{0.6} \mathrm{Co}_{0.2} \mathrm{O}_{2}$.

stoichiometry $(\sim 0.5 \mathrm{Na} / \mathrm{TM})$ and hence lower capacity than their P2 $\mathrm{Na}_{\mathrm{x}} \mathrm{MO}_{2}$ counterparts. Furthermore, they are difficult to synthesize as pure phase. ${ }^{23}$

The targeted $\mathrm{O} 3$ and $\mathrm{P} 2$ materials were all synthesized as pure phases as confirmed by their XRD patterns (Fig. S3) with an exception to $\mathrm{O} 3 \mathrm{NaNi}_{0.5} \mathrm{Mn}_{0.5} \mathrm{O}_{2}$ which was always contaminated by a small amount of $\mathrm{NiO}(\sim 5 \%)$ regardless of the synthesis conditions we have tried. Next, the synthesized sodium layered oxides and the NVPF material were tested for their stability toward moisture in air by storing a part of the samples under controlled humidity of $\mathrm{RH} \sim 55 \%$ and analyzing the evolution of XRD patterns after 24 hours of storage. ${ }^{24}$ Most of the studied sodium layered oxides show an evolution in the XRD patterns with the appearance of new peaks due to the presence of water intercalated phases and/or sodium carbonate (Fig. S4). This demonstrates the reactivity of sodium layered oxides toward moisture, in contrast to the NVPF material that shows no change in the XRD pattern before and after being exposed to moisture (Fig. S5). Hence, all the sodium layered oxides under study were stored in an argon filled glove box whereas the NVPF material was stored in air and dried at $100^{\circ} \mathrm{C}$ under vacuum for $12 \mathrm{~h}$ prior to being used for electrochemical analysis.

The electrochemical performances were tested in sodium half cells, and the voltage composition curves, shown for the $\mathrm{P} 2$ and $\mathrm{O} 3$ phases, on the left and right of Fig. 1, respectively are in full agreement with previous findings. ${ }^{21,25-29}$ Whatever the $\mathrm{O} 3$ phase tested, a reversible capacity ranging from 100 to $150 \mathrm{mAh} \mathrm{g}^{-1}$ was observed when the cells were cycled between $2.2 \mathrm{~V}$ and $4 \mathrm{~V}$. The discharge capacity is nearly equal to that of charge capacity with a small first cycle irreversibility $(\sim 0.1 \mathrm{Na})$. On the other hand, the P2 phases behave quite differently. Indeed, although only $0.45 \mathrm{Na}^{+}$can be removed from $\mathrm{P} 2-\mathrm{Na}_{0.67} \mathrm{Fe}_{0.5} \mathrm{Mn}_{0.5} \mathrm{O}_{2}$ on charge (full charge capacity of $120 \mathrm{mAh} \mathrm{g}^{-1}$ ), the phase can uptake nearly $0.8 \mathrm{Na}^{+}$on the following discharge till $1.5 \mathrm{~V}$ leading to a reversible capacity as high as $\sim 200 \mathrm{mAh} \mathrm{g}^{-1}$. The electrochemically formed $\mathrm{Na} \sim 0.8 \mathrm{Fe}_{0.5} \mathrm{Mn}_{0.5} \mathrm{O}_{2}$ can then be cycled over the $1.5-4.2 \mathrm{~V}$ voltage range with limited capacity decay. 


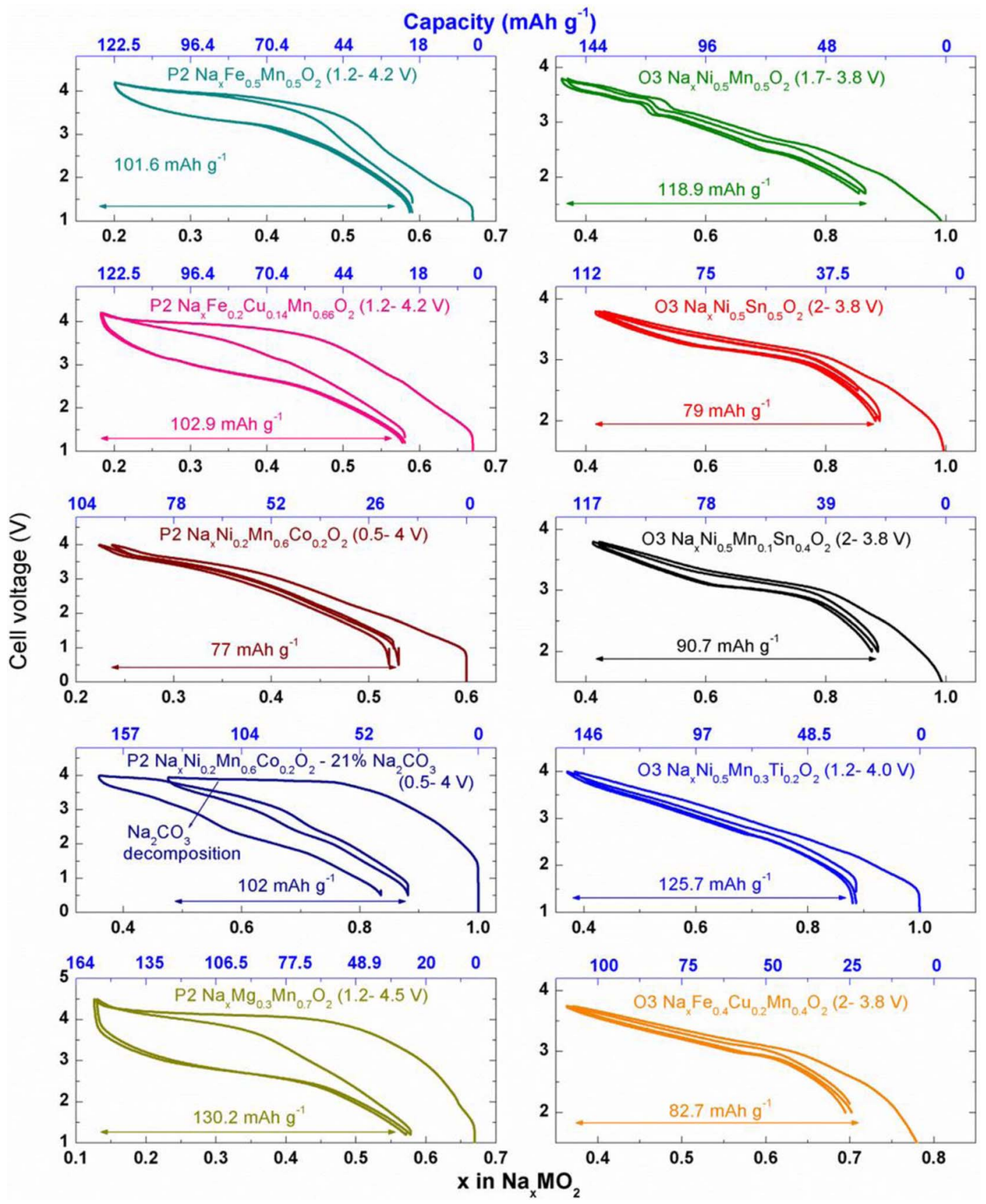

Figure 2. Galvanostatic charge-discharge profiles of the studied (left) P2 and (right) O3 sodium layered oxides in Na-ion full cells. Hard carbon coated on Al foil is used as negative electrode and the cells were cycled at $\mathrm{C} / 20$ rate. The voltage window used for the cycling and the obtained reversible capacities are indicated in their respective cycling curves. The long plateau observed at $4 \mathrm{~V}$ in the first and second charge of $\mathrm{P} 2 \mathrm{Na}_{0.6} \mathrm{Ni}_{0.2} \mathrm{Mn}_{0.6} \mathrm{Co}_{0.2} \mathrm{O}_{2}+21 \% \mathrm{Na}_{2} \mathrm{CO}_{3}$ composite is due to the irreversible decomposition of $\mathrm{Na}_{2} \mathrm{CO}_{3}$. For calculation purposes, the total sodium in the composite $\mathrm{P} 2 \mathrm{Na}_{0.6} \mathrm{Ni}_{0.2} \mathrm{Mn}_{0.6} \mathrm{Co}_{0.2} \mathrm{O}_{2}+21 \% \mathrm{Na}_{2} \mathrm{CO}_{3}$ is used in the $\mathrm{x}$-axis; hence the starting sodium stoichiometry is mentioned as 1 , however the actual composition is $\mathrm{Na}_{0.6} \mathrm{Ni}_{0.2} \mathrm{Mn}_{0.6} \mathrm{Co}_{0.2} \mathrm{O}_{2}$.

Next, we have used the same $\mathrm{P} 2$ and $\mathrm{O} 3$ phases in full cell configuration with hard carbon (HC) as negative electrode material. They were tested using different voltage windows and we only report (Fig. 2) the optimized data in terms of practical capacity and cycle life. The voltage-composition profiles over the few cycles in Fig. 2 show a nearly identical irreversibility between the first charge and subsequent discharge independently of the structure (O3 or P2). Similar to the Li-ion technology, this initial irreversible capacity is associated with the formation of a solid electrolyte interphase (SEI) at the carbon negative electrode that consumes Na ions. As a common feature, the $\mathrm{O} 3$ phases display a smaller polarization than the $\mathrm{P} 2$ phases with the exception of $\mathrm{Na}_{\mathrm{x}} \mathrm{Ni}_{0.2} \mathrm{Mn}_{0.6} \mathrm{Co}_{0.2} \mathrm{O}_{2}$ which will be discussed later.
Next, we compare (Fig. 3) the specific energies of the studied P2 and $\mathrm{O} 3$ phases in half cell and full cell configurations. These energies were calculated considering the positive active material weight alone in order to compare half cell and full cell data. Nearly $\sim 20 \%$ reduction in energy is observed for the $\mathrm{O} 3$ phases when full cells rather than half cells are assembled. The reasons for such a loss are twofold and enlist i) a decrease in capacity due to Na-ions consumed in the formation of SEI and ii) a reduction of the voltage when replacing Na-metal by hard carbon at the negative electrode. Note that this loss is quite larger for the $\mathrm{P} 2$ phases as it reaches more than $33 \%$ of the values reported for half cells. Bearing in mind that in full Na-ion cells, the $\mathrm{Na}^{+}$ions are provided only by the positive electrode, the extra 

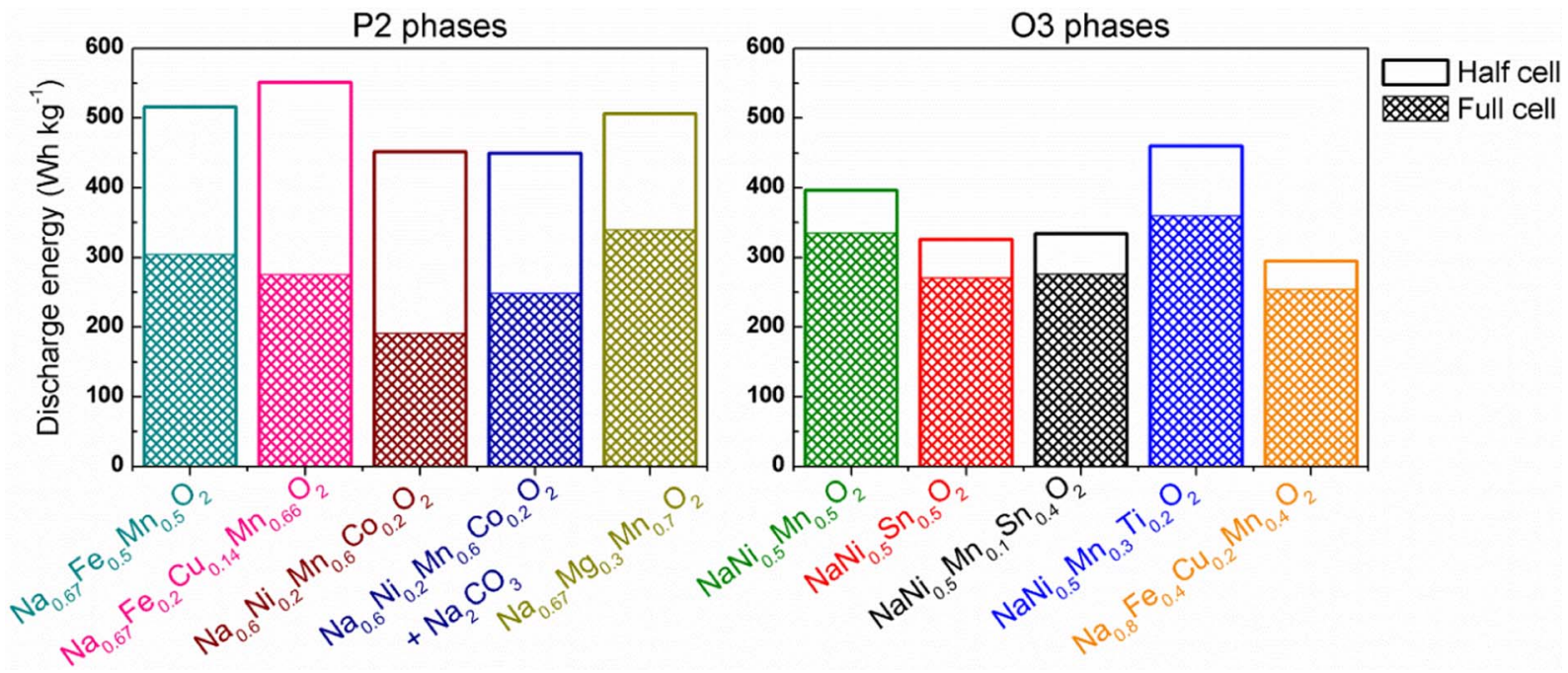

Figure 3. Bar chart comparing the specific energy of the sodium layered oxides in half cell and full cell configurations. The total height and the height of the pattern marked portions represent the specific energy in Na-metal half cell and Na-ion full cell configurations respectively. The energies were calculated based on the positive material weight alone.

capacity achieved by the formation of $\mathrm{Na}_{0.67+\mathrm{x}} \mathrm{MO}_{2}$ in Na-half cells is not useable in Na-ion full cells. As a result, because of the initial Nadeficiency pertaining to the $\mathrm{P} 2$ phase, their attractive energy density of $500-550 \mathrm{Wh} \mathrm{kg}^{-1}$ in half cells is reduced to $300 \mathrm{Wh} \mathrm{kg}^{-1}$ in full cells. So, although a huge specific energy is reported for $\mathrm{P} 2$ type sodium layered oxides, they are of no practical interest for the $\mathrm{Na}$-ion technology unless ways to circumvent this non-stoichiometry in sodium are found.

To alleviate this issue, a few directions were explored such as the pre-sodiation of the $\mathrm{P} 2$ phase by chemical/physical (ballmilling) ${ }^{30}$ or electrochemical means with therefore the drawback of adding an extra step to obtain a highly moisture sensitive powder that complicates the cell assembling process. More attractive, has been the use of appropriate amounts of $\mathrm{Na}$ sacrificial salts $\left(\mathrm{Na}_{2} \mathrm{CO}_{3}, \mathrm{Na}_{3} \mathrm{~N}, \mathrm{Na}_{3} \mathrm{P}\right)^{21,30,31}$ acting as a sodium reservoir to electrochemically form within the cell the P'2- $\mathrm{NaMO}_{2}$ phase as exemplified by the $\mathrm{P} 2 \mathrm{Na}_{0.6} \mathrm{Ni}_{0.2} \mathrm{Mn}_{0.6} \mathrm{Co}_{0.2} \mathrm{O}_{2}+$ $\mathrm{Na}_{2} \mathrm{CO}_{3}$ composite reported in the present study (Figs. 1 and $2,4^{\text {th }}$ graph down to the left). However, the sodiated P'2 $\mathrm{NaMO}_{2}$ phase is metastable, the reason why it cannot be synthesized by a ceramic process. ${ }^{16}$ Therefore, we observed that the repeated P2-P'2 phase transition reduces the long term cyclability of the full Na-ion cell (Fig. S6). In short, the use of a sacrificial salt to obtain the full capacity of the $\mathrm{P} 2 \mathrm{Na}_{\mathrm{x}} \mathrm{MO}_{2}$ layered oxides is a scientifically attractive concept, however it does not hold up in practical applications.

In light of the recently discovered reversible anionic redox chemistry that enabled the design of high capacity positive electrodes for Li-ion batteries, ${ }^{32,33}$ another alternative to increase the capacity of $\mathrm{Na}$-based layered oxides has been the development of the P2 $\mathrm{Na}_{2 / 3} \mathrm{Mg}_{0.28} \mathrm{Mn}_{0.72} \mathrm{O}_{2}$ and $\mathrm{P} 2 \mathrm{Na}_{2 / 3} \mathrm{Zn}_{\mathrm{y}} \mathrm{Mn}_{1-\mathrm{y}} \mathrm{O}_{2}$ layered phases showing anionic redox activity. ${ }^{20,34}$ However, a drastic difference is that the anionic redox process is associated to an excess of $\mathrm{Li}$ (Li-rich) for Li-based layered oxides as opposed to a $\mathrm{Na}$ understoichiometry (less than one Na per transition metal ion (TM)) for the P2 sodium phases, hence impeding the benefit of anionic activity, unlike in the Li-rich phases. Nevertheless, a specific energy as high as $\sim 510 \mathrm{Wh} \mathrm{kg}^{-1}$ could be achieved with $\mathrm{P} 2 \mathrm{Na}_{2 / 3} \mathrm{Mg}_{0.3} \mathrm{Mn}_{0.7} \mathrm{O}_{2}$ in $\mathrm{Na}$ half cells with a good capacity retention (Fig. 1, $5^{\text {th }}$ graph down on the left). Therefore, as before and due to the limited amount of $\mathrm{Na}$ that can be removed from the pristine phase, this specific energy is reduced to $360 \mathrm{Wh} \mathrm{kg}^{-1}$ when full Na-ion cells are assembled (Fig. 3). Besides, additional drawbacks with these P2-phases are their large hysteresis between the charge and discharge processes (see the cycling profile of $\mathrm{Na}_{0.67} \mathrm{Mg}_{0.3} \mathrm{Mn}_{0.7} \mathrm{O}_{2}$ in Fig. 2; $5^{\text {th }}$ graph down on the left) leading to poor energy efficiency (Fig. S7). Similar hysteresis is also ob- served with $\mathrm{P} 2 \mathrm{Na}_{0.67} \mathrm{Fe}_{0.5} \mathrm{Mn}_{0.5} \mathrm{O}_{2}$ and $\mathrm{P} 2 \mathrm{Na}_{0.67} \mathrm{Fe}_{0.2} \mathrm{Cu}_{0.14} \mathrm{Mn}_{0.66} \mathrm{O}_{2}$ where competing cationic $\mathrm{Fe}^{3+} / \mathrm{Fe}^{(3+\mathrm{n})+}$ and anionic redox processes are reported. ${ }^{25,26}$ The origin of such hysteresis, which is nested in the sluggish kinetics of the anionic redox process, has been demonstrated to be an intrinsic property of insertion materials relying on anionic redox activity, ${ }^{35}$ hence further limiting the practicality of the above P2 phases and more so as they are deficient in Na.

Lastly, another figure of merit, besides specific energy, in comparing the positive attributes of the $\mathrm{P} 2$ against the $\mathrm{O} 3$ phase is the power capability. To instruct this point we decided to determine the rate capability for both $\mathrm{P} 2 \mathrm{Na}_{0.67} \mathrm{Cu}_{0.14} \mathrm{Fe}_{0.2} \mathrm{Mn}_{0.66} \mathrm{O}_{2}$ and $\mathrm{O} 3$ $\mathrm{Na}_{0.8} \mathrm{Cu}_{0.2} \mathrm{Fe}_{0.4} \mathrm{Mn}_{0.4} \mathrm{O}_{2}$ phases which have relatively similar transition metal ions stoichiometry. It can be seen from the results summarized in Fig. 4 that the $\mathrm{O} 3$ phase exhibits better rate capability as it retains $\sim 90 \%$ of its capacity vs. $80 \%$ for the $\mathrm{P} 2$ phase at $1 \mathrm{C}$ rate. This result is surprising as it goes against previous theoretical predictions claiming a better rate capability of the $\mathrm{P} 2$ phase as compared

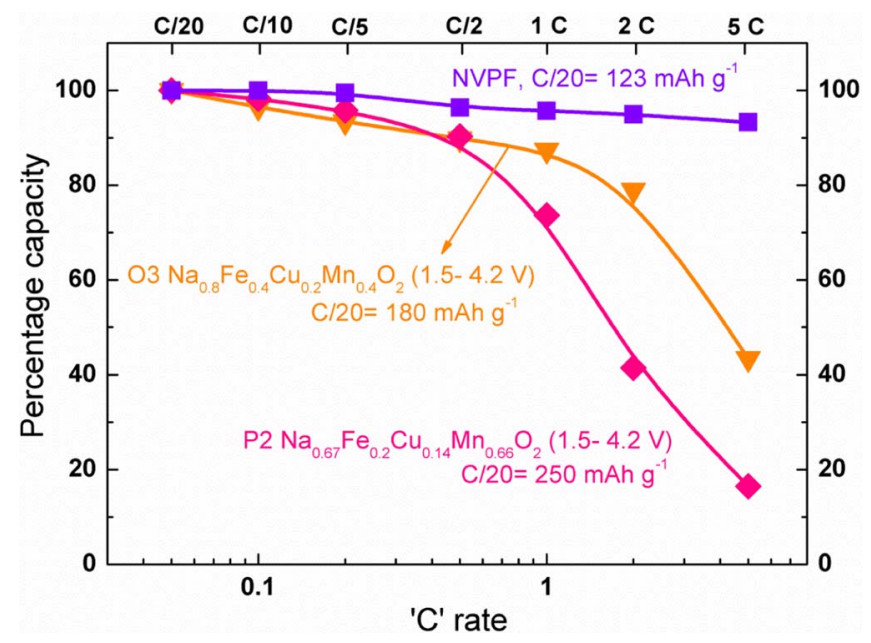

Figure 4. Comparison of power rate capability of $\mathrm{P} 2 \mathrm{Na}_{0.67} \mathrm{Fe}_{0.2} \mathrm{Cu}_{0.14}$ $\mathrm{Mn}_{0.66} \mathrm{O}_{2}, \mathrm{O} 3 \mathrm{Na}_{0.8} \mathrm{Fe}_{0.4} \mathrm{Cu}_{0.2} \mathrm{Mn}_{0.4} \mathrm{O}_{2}$ and NVPF. The experiments were carried out in Na-metal half cells in which the cells were first charged at $\mathrm{C} / 10$ rate followed by a signature curve analyses on discharge with the cycling rate ranging from $5 \mathrm{C}, 2 \mathrm{C}$ etc to $\mathrm{C} / 20$. The voltage window used for the sodium layered oxides is $1.5-4.2 \mathrm{~V}$; however, the NVPF is charged to $4.8 \mathrm{~V}$ on first charge to remove $2.35 \mathrm{Na}$ and then discharged down to $3 \mathrm{~V}$. 


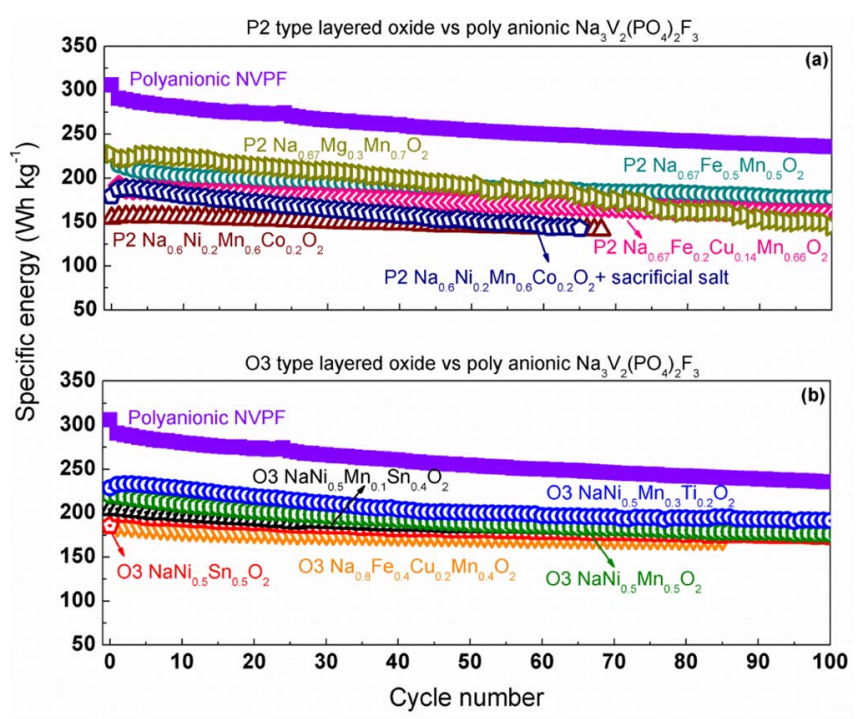

Figure 5. Comparison of specific energies of the (a) $\mathrm{P} 2 \mathrm{Na}_{\mathrm{x}} \mathrm{MO}_{2} / \mathrm{HC}$ and (b) $\mathrm{O} 3 \mathrm{NaMO}_{2} / \mathrm{HC} \mathrm{Na}$-ion cells with that of the benchmark polyanionic compound NVPF. The discharge specific energies were used for the comparison and all energies were normalized for the total weight of the positive and negative electrode active materials. The data is collected from the cell cycling shown in Fig. 2 for sodium layered oxides and, in Fig. S1 for NVPF.

to the $\mathrm{O} 3$ phase. $^{7}$ To rationalize such behavior, we should recall that the sodium diffusion pathway in the $\mathrm{O} 3$ phase enlists a $\mathrm{Na}^{+}$hoping between octahedral sites via a tetrahedral site $(\mathrm{O}-\mathrm{T}-\mathrm{O})$ while there is a direct and less energetic $\mathrm{Na}^{+}$hoping between two neighbors' prismatic sites in the P2 phase. Nevertheless, this crude view does not take into account the structural evolution of the $\mathrm{O} 3$ and $\mathrm{P} 2$ phases during cycling, which reversibly transform into a $\mathrm{P} 3$ and $\mathrm{O} 2 / \mathrm{OP} 4$ type-phase, respectively. Altogether, this means that irrespective of the structure of the starting material, both phases end up having $\mathrm{Na}^{+}$ in prismatic sites at one stage, and in octahedral sites at another stage of the insertion-disinsertion process. Thus, it is not unlikely that $\mathrm{O} 3$ electrodes could present higher rate capabilities than P2 electrodes as we observed, further stressing that $\mathrm{P} 2$ electrodes are not automatically the best candidates for NIBs. The NVPF electrodes provide by far a better choice in terms of rate capability (Fig. 4) since nearly $95 \%$ of their initial energy can be used in less than 20 minutes (5C).

From this survey we can conclude that the $\mathrm{P} 2 \mathrm{Na}_{\mathrm{x}} \mathrm{MO}_{2}$ phases as such or boosted by the use of either sacrificial salts or of the anionic redox process, falls short when implemented in full Na-ion cells. Fig. 5a compiles the specific energy and cyclability of the studied P2 phases and compares with that of the benchmark polyanionic NVPF/HC Naion cells. The specific energies were normalized for the total weight of positive and negative active electrode material. Fig. 5a indeed shows that all the studied $\mathrm{P} 2 \mathrm{Na}_{\mathrm{x}} \mathrm{MO}_{2} / \mathrm{HC}$ full cells exhibit specific energies ranging from $\sim 200-250 \mathrm{Wh} \mathrm{kg}^{-1}$, which is much less than the $>300 \mathrm{Wh} \mathrm{kg}^{-1}$ that can be achieved with NVPF/HC full cells. All materials show good capacity retention with $\sim 90 \%$ of the initial capacity retained after 100 cycles with the exception of materials with anionic activity and sacrificial $\mathrm{Na}_{2} \mathrm{CO}_{3}$ which show comparatively higher degradations.

Similarly and using the same protocol, we have benchmarked the selected $\mathrm{O} 3$ phases that contain $\sim 1$ sodium/TM, against NVPF/HC $\mathrm{Na}$-ion cells. In spite of the greater amount of $\mathrm{Na}$ ( 1 vs. $0.6-0.7$ in $\mathrm{P} 2$ phases) in the starting material, all the $\mathrm{O} 3$ phases studied herein exhibit poor specific energy in comparison to the NVPF compound as shown in Fig. 5b. The main reason is nested in the difficulties to remove more than $0.5 \mathrm{Na}^{+}$from the $\mathrm{O} 3$ phase because of structural reasons as for $\mathrm{LiCoO}_{2}$ in its early stage. Hence, intensive amount of in situ structural analyses have been devoted to the monitoring of structural changes triggered by the removal of $\mathrm{Na}^{+}$from $\mathrm{O} 3-\mathrm{NaMO}_{2}$ phases. ${ }^{29,36}$

Further comparing all of the studied $\mathrm{O} 3 \mathrm{NaMO}_{2}$ materials, a nearly common feature is the existence of two major phase transitions (Fig. 6) namely (a) $\mathrm{O} 3 \mathrm{NaMO}_{2} \Leftrightarrow \mathrm{P} 3 \mathrm{Na} \sim 0.5 \mathrm{MO}_{2}$ and (b) $\mathrm{P} 3 \mathrm{Na} \sim 0.5 \mathrm{MO}_{2} \Leftrightarrow \mathrm{O} 3$ $\mathrm{Na}_{\mathrm{y}} \mathrm{MO}_{2}$ (where $\mathrm{y}<0.5$ and varies with the nature of $\mathrm{M}$ ) depending on the voltage window used for cycling. The origin of these phase transformations is commonly believed to be nested in minimizing (i)

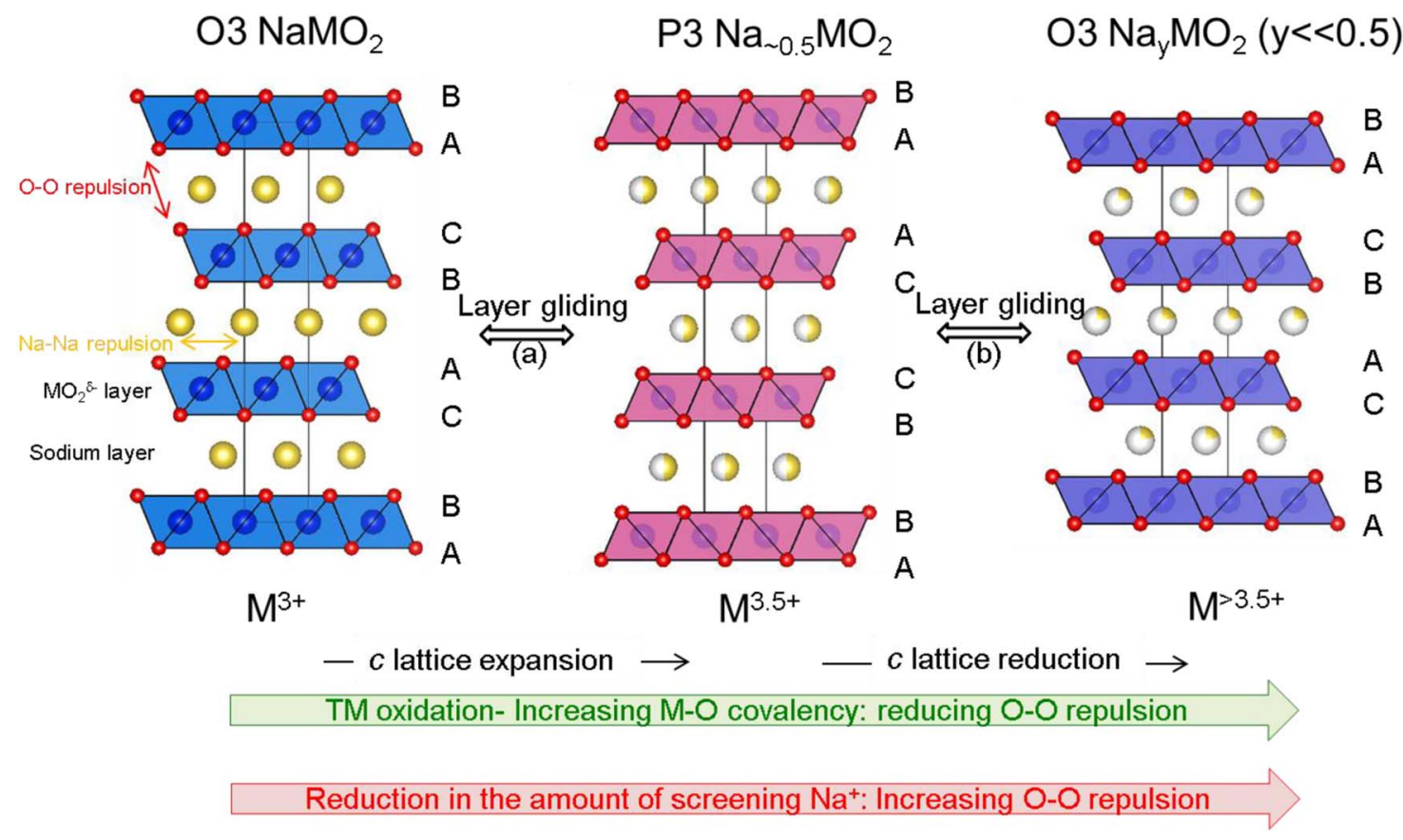

Figure 6. The two major structural evolutions (a) $\mathrm{O} 3 \mathrm{NaMO}_{2} \Leftrightarrow \mathrm{P} 3 \mathrm{Na} \sim 0.5 \mathrm{MO}_{2}$ and (b) $\mathrm{P} 3 \mathrm{Na} \sim 0.5 \mathrm{MO}_{2} \Leftrightarrow \mathrm{O} 3 \mathrm{Na}_{\mathrm{y}} \mathrm{MO}_{2}$ (where y $<0.5$ and varies with the nature of $\mathrm{M}$ ), widely observed in $\mathrm{O} 3 \mathrm{NaMO}_{2}$ materials during sodium de-insertion. The blue, red, yellow and white circles represent the transition metal (M), oxygen, sodium atoms and vacancies respectively. The various inter and intra layer repulsions that control the stability of each phase are shown in the figure. 

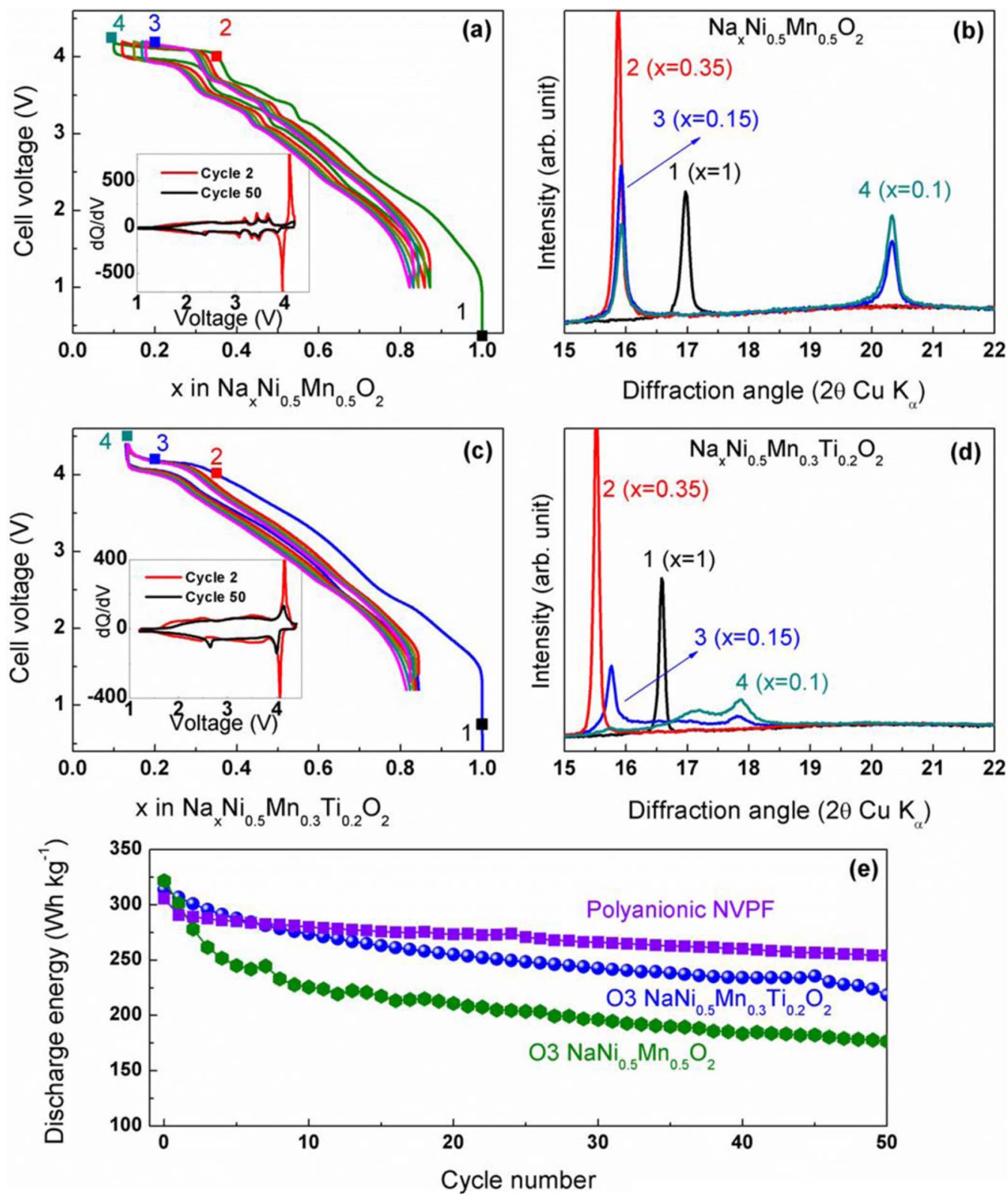

Figure 7. (a) Galvanostatic charge-discharge profiles of the (a) $\mathrm{O} 3 \mathrm{NaNi}_{0.5} \mathrm{Mn}_{0.5} \mathrm{O}_{2} / \mathrm{HC}$ and (c) $\mathrm{O} 3 \mathrm{NaNi}_{0.5} \mathrm{Mn}_{0.3} \mathrm{Ti}_{0.2} \mathrm{O}_{2} / \mathrm{HC}$ Na-ion full cells cycled between 1.2- $4.2 \mathrm{~V}$ and 1.2-4.4 $\mathrm{V}$ respectively. The derivative plots for the first and $50^{\text {th }}$ cycle are shown as inset in the corresponding cycling profiles. The XRD patterns for the compositions marked 1, 2, 3 and 4 in (a) and (c) were analyzed in their equivalent half-cell cycling and the evolutions of the (003) peak is shown in (b) $\mathrm{Na}_{\mathrm{x}} \mathrm{Ni}_{0.5} \mathrm{Mn}_{0.5} \mathrm{O}_{2}$ and (d) $\mathrm{Na}_{\mathrm{x}} \mathrm{Ni}_{0.5} \mathrm{Mn}_{0.3} \mathrm{Ti}_{0.2} \mathrm{O}_{2}$; the phases observed at each point are identified to be, (1) single phase O3, (2) O-type/P-type phase for Ti-unsubstituted and Ti-substituted phases respectively and (3,4) biphasic mixture in which one phase is $\mathrm{O}_{3} \mathrm{Na}_{\mathrm{y}} \mathrm{MO}_{2}$, where $\mathrm{y}=0.15$ and 0.1 respectively. (e) Comparison of specific energy and cyclability of the $\mathrm{NaNi}_{0.5} \mathrm{Mn}_{0.5} \mathrm{O}_{2} / \mathrm{HC}$ and $\mathrm{NaNi}_{0.5} \mathrm{Mn}_{0.3} \mathrm{Ti}_{0.2} \mathrm{O}_{2} / \mathrm{HC}$ Na-ion cells with that of polyanionic NVPF/HC Na-ion cell. In all cases, the positive electrodes were used as loose powders and the specific energies were calculated for the total weight of positive and negative electrode active materials.

the $\mathrm{O}-\mathrm{O}$ inter-layer repulsion, (ii) the $\mathrm{Na}-\mathrm{Na}$ intra-layer repulsions and (iii) the Na-M interlayer repulsions so as to obtain the most thermodynamically stable intermediates, which were predicted as well by DFT calculations. ${ }^{37,38}$ In light of such competing interactions and because of a specific $\mathrm{Na}^{+}$-vacancy ordering, the $\mathrm{P} 3 \mathrm{Na} \sim 0.5 \mathrm{MO}_{2}$ phase, shows higher stability, hence explaining why a higher energy is needed to remove more sodium. ${ }^{39}$ This is reflected in the appearance of a potential jump in the cycling curve (Fig. S8). At this stage, nearing the complete oxidation, the remaining amount of $\mathrm{Na}^{+}$does not screen sufficiently the inter-layer $\mathrm{O}-\mathrm{O}$ repulsive interactions, however the negative charge $(\delta-)$ on the $\mathrm{MO}_{2}{ }^{\delta-}$ layers decreases due to the oxidized transition metal ions. This leads to a gliding of the $\mathrm{MO}_{2}$ layers on top of each other in order to minimize the energy, hence triggering a shift toward another $\mathrm{O} 3$ structure. Nevertheless, better cycle life is achieved in most of the materials studied so far in the literature by avoiding such high voltage phase transition $\left(\mathrm{P} 3 \mathrm{Na}_{\sim 0.5} \mathrm{MO}_{2} \Leftrightarrow \mathrm{O} 3\right.$ $\left.\mathrm{Na}_{\mathrm{y}} \mathrm{MO}_{2}\right) .{ }^{40,41}$ Needless to say that stabilizing this high voltage phase transition is essential to realize further improvements in the specific energy of the $\mathrm{O} 3 \mathrm{NaMO}_{2}$ materials.

The striking effect of such structural transitions on the performances of the materials is illustrated by the cycling properties of $\mathrm{Na}_{\mathrm{x}} \mathrm{Ni}_{0.5} \mathrm{Mn}_{0.5} \mathrm{O}_{2} / \mathrm{HC}$ cells over the extended voltage window of $2-4.2 \mathrm{~V}$. Note here that the voltage jump occurring at $\mathrm{x} \sim 0.5$ is followed by a long plateau region observed at $4.2 \mathrm{~V}$ (Fig. 7a), hence indicating 
that a total of $\sim 0.9 \mathrm{Na}^{+}$could be removed from the structure leading to a capacity of $200 \mathrm{mAh} \mathrm{g}^{-1}$. However, this high capacity degrades continuously on subsequent cycling with mainly the decay of the long voltage plateau as clearly indicated by the complete disappearance of the $4.2 \mathrm{~V}$ peak after 50 cycles in the derivative plot (inset in Fig. 7a). To better understand the structure-capacity decay relationship, we have carried out in situ XRD analysis of the $\mathrm{NaNi}_{0.5} \mathrm{Mn}_{0.5} \mathrm{O}_{2}$ material in sodium half cells. For reasons of conciseness we only report the evolution of the (003) peak in Fig. 7b for various compositions marked by points 1, 2, 3 and 4 on the corresponding voltage-composition curve (Fig. 7a). We confirm the $\mathrm{O} 3 \rightarrow \mathrm{P} 3 \rightarrow \mathrm{O} 3$ sequential phase changes, but note a considerable change in the $c$-axis parameter associated to the $\mathrm{P} 3 \rightarrow \mathrm{O} 3$ transition which occurs at the very end of charge. We believe this to be the reason for the poor reversibility and the capacity decay upon cycling.

In light of such a finding, a simple solution to improve the cyclability of these $\mathrm{Na}_{\mathrm{y}} \mathrm{MO}_{2}$ materials at high voltages could consist in reducing the lattice contraction during the $\mathrm{P} 3 \rightarrow \mathrm{O} 3$ phase transition which is mainly governed by the $\mathrm{O}-\mathrm{O}$ inter layer repulsion. This calls for a careful tuning of the charge localization on the oxygen, hence the iono-covalency of the M-O bonds. We have recently tested this approach by pursuing chemical substitution with elements having empty/full $\mathrm{d}$ orbitals such as $\mathrm{Ti}^{4+}$ or $\mathrm{Sn}^{4+}$ bearing in mind that the ionicity follows the trend $\mathrm{Sn}^{4+}>\mathrm{Ti}^{4+}>\mathrm{Mn}^{4+} .{ }^{27}$ We found that with $\mathrm{Ti}^{4+}$, which is less ionic than $\mathrm{Sn}^{4+}$ and more ionic than $\mathrm{Mn}^{4+}$, it is possible to improve the cyclability of the material even when cycled over the large $2-4.5 \mathrm{~V}$ voltage window (Fig. 7c and the derivative shown as inset). The corresponding in situ XRD (Fig. 7d) still shows the O3 $\mathrm{NaMO}_{2} \Leftrightarrow \mathrm{P} 3 \mathrm{Na}_{0.5} \mathrm{MO}_{2} \Leftrightarrow \mathrm{O} 3 \mathrm{Na}_{0.1} \mathrm{MO}_{2}$ structural evolution but the (003) peak only changes from $16.5^{\circ}$ (pristine) to $17.7^{\circ}$ for the fully oxidized $\mathrm{O} 3 \mathrm{Na}_{0.1} \mathrm{MO}_{2}$ phase which corresponds to a volume change of $\Delta \mathrm{V} / \mathrm{V}=15 \%$ from the pristine $\mathrm{O} 3 \mathrm{NaNi}_{0.5} \mathrm{Mn}_{0.3} \mathrm{Ti}_{0.2} \mathrm{O}_{2}$. Such a comparatively reduced change in unit cell volume (15\% vs $23 \%$ for the $\mathrm{NaNi}_{0.5} \mathrm{Mn}_{0.5} \mathrm{O}_{2} / \mathrm{Na}_{0.1} \mathrm{Ni}_{0.5} \mathrm{Mn}_{0.5} \mathrm{O}_{2}$ ) during cycling helps in stabilizing the phase transition, hence explaining why $\mathrm{Ti}^{4+}$ substituted phases show better retention on long cycling compared to the unsubstituted phase $\mathrm{NaNi}_{0.5} \mathrm{Mn}_{0.5} \mathrm{O}_{2}$ (Fig. 7e). In contrast, moving to a more ionic $\mathrm{NaNi}_{0.5} \mathrm{Sn}_{0.5} \mathrm{O}_{2}$ material was found to be detrimental as the removal of $\mathrm{Na}^{+}$requires a higher charging voltage to trigger the $\mathrm{P} 3 \rightarrow \mathrm{O} 3$ phase which is highly irreversible (Fig. S9). This indicates the existence of a delicate balance between the ionicity of the $3 \mathrm{~d}$ metal-O bonding and the amplitude of the structural P3-O3 transition in identifying the best $\mathrm{O} 3-\mathrm{NaMO}_{2}$ phase.

Finally, we compare the cycling stability of the $\mathrm{NaNi}_{0.5} \mathrm{Mn}_{0.5} \mathrm{O}_{2} /$ $\mathrm{HC}$ and $\mathrm{NaNi}_{0.5} \mathrm{Mn}_{0.3} \mathrm{Ti}_{0.2} \mathrm{O}_{2} / \mathrm{HC}$ Na-ion cells in the extended $2-4.5 \mathrm{~V}$ voltage window, against $\mathrm{NVPF} / \mathrm{HC}$ ones (Fig. 7e). Note that initially, all cells show nearly the similar energy density, but the cycling stability decays in the order $\mathrm{NaNi}_{0.5} \mathrm{Mn}_{0.5} \mathrm{O}_{2} / \mathrm{HC}>\mathrm{NaNi}_{0.5} \mathrm{Mn}_{0.3} \mathrm{Ti}_{0.2} \mathrm{O}_{2} / \mathrm{HC}>$ NVPF/HC. As expected, NVPF that consists of a stable 3D framework structure shows enough flexibility for repeated reversible sodium insertion without causing considerable changes in the structure and its volume $(\Delta \mathrm{V} / \mathrm{V} \sim 2 \%){ }^{15}$ This contrasts with the stacked $\mathrm{MO}_{2}$ layers in sodium layered oxides that get stabilized mainly by the screening $\mathrm{Na}^{+}$ions in between the layers and for which the removal of $\mathrm{Na}^{+}$ leads to phase transitions and volume changes. Such phase transformations are intrinsic to the Na-based layered oxides and therefore cannot be fully eliminated but only reduced as we've illustrated above with the $\mathrm{Ti}^{4+}$ substitution. The introduction of pillaring ions/groups between the $\mathrm{MO}_{2}$ layers could help in reducing the layer gliding all the while eliminating the phase transitions. However, this would come at the expense of $\mathrm{Na}^{+}$diffusion and therefore to decreased rate capabilities.

\section{Conclusions}

We have benchmarked the electrochemical performances of $\mathrm{Na}$-ion cells based on hard carbon negative electrodes and sodium layered oxide positive electrodes having either $\mathrm{O} 3$ or $\mathrm{P} 2$ structures with or with- out anionic redox activity, against $\mathrm{Na}_{3} \mathrm{~V}_{2}\left(\mathrm{PO}_{4}\right)_{2} \mathrm{~F}_{3} / \mathrm{HC}$ cells. Whatever the figures of merit we have checked such as specific energy, cyclability as well as rate capability, the three dimensional $\mathrm{Na}_{3} \mathrm{~V}_{2}\left(\mathrm{PO}_{4}\right)_{2} \mathrm{~F}_{3}$ (NVPF) phase outperforms the layered oxides. Such superiority of NVPF will last until some of the main challenges associated to the layered oxides such as low redox potential, limited reversible capacity, Na-driven structural instability and moisture sensitivity can be solved. Further pursuing the anionic redox chemistry with Na layered oxides to reach such goals has little chances to succeed. Nevertheless, let's hope that chemistry surprises us. Even then, success is not guaranteed in light of the major roadblocks preventing the practicality of anionic activity in Li-ion batteries that are still awaiting a solution in spite of 10 years of research.

Fluorine substitution can be envisioned as a possible way to raise the voltage but the fluoride chemistry with layered oxides is complex although we are witnessing a regain of hope with some recent work dealing with F-based disordered rock salt structures. Besides playing with $\mathrm{F}$, cationic substitution is by all means the most favorable way to adjust material structural stability, redox potential and so on as nicely demonstrated for polyanionic compounds. Such substitution chemistry has already been heavily pursued with layered phases resulting in compounds having at least 3 to $43 d$-metals with no or limited performance gain. So chances of identifying better $3 d$ metal combinations are slim unless we can obtain guidance from theorists. We have been pursuing this last approach and isolated a new layered phase that compares favorably with NVPF, except in terms of rate capability, which will be reported in a forthcoming paper. ${ }^{42}$

\section{Acknowledgments}

J.-M.T. acknowledges funding from the European Research Council (ERC) (FP/2014)/ERC, Grant-Project 670116-ARPEMA. The authors thank Patrick Rozier, CIRIMAT for $\mathrm{Na}_{0.67} \mathrm{Mg}_{0.3} \mathrm{Mn}_{0.7} \mathrm{O}_{2}$ material and Renald David, LRCS, Amiens for NVPF and hard carbon electrodes.

\section{ORCID}

Sathiya Mariyappan (10 https://orcid.org/0000-0003-2851-5906 Jean Marie Tarascon (D) https://orcid.org/0000-0002-7059-6845

\section{References}

1. R. Schmuch, R. Wagner, G. Hörpel, T. Placke, and M. Winter, "Performance and Cost of Materials for Lithium-Based Rechargeable Automotive Batteries." Nat. Energy, 3, 267 (2018)

2. K. Kariatsumari, H. Kume, H. Yomogita, and P. Keys, Winning in the Gigantic New EV Market 17 ((NEKKEI ELECTRONICS ASIA cover story).

3. D. Larcher and J.-M. Tarascon, "Towards Greener and More Sustainable Batteries for Electrical Energy Storage." Nat. Chem., 7, 19 (2015).

4. M. Armand and J.-M. Tarascon, "Building Better Batteries." Nature, 451, 652 (2008)

5. J.-Y. Hwang, S.-T. Myung, and Y.-K. Sun, "Sodium-Ion Batteries: Present and Future." Chem. Soc. Rev., 46, 3529 (2017)

6. Z. Dai, U. Mani, H. T. Tan, and Q. Yan, "Advanced Cathode Materials for Sodium-Ion Batteries: What Determines Our Choices?" Small Methods, 1, 1700098 (2017).

7. K. Kubota, S. Kumakura, Y. Yoda, K. Kuroki, and S. Komaba, "Electrochemistry and Solid-State Chemistry of $\mathrm{NaMeO}_{2}(\mathrm{Me}=3 \mathrm{~d}$ Transition Metals)." Adv. Energy Mater, 8, 1703415 (2018).

8. J. Deng, W.-B. Luo, S.-L. Chou, H.-K. Liu, and S.-X. Dou, "Sodium-Ion Batteries: From Academic Research to Practical Commercialization." Adv. Energy Mater, 8 , 1701428 (2018).

9. Y. Fang, J. Zhang, L. Xiao, X. Ai, Y. Cao, and H. yang, "Phosphate Framework Electrode Materials for Sodium Ion Batteries." Adv. Sci., 4, 1600392 (2017).

10. S. Roberts and E. Kendrick, "The Re-Emergence of Sodium Ion Batteries: Testing, Processing, and Manufacturability." Nanotechnol. Sci. Appl., 11, 23 (2018).

11. L. Li, S. Zheng, J. Yang, Z. Shao, and Z. Guo, "Recent Progress on Sodium Ion Batteries: Potential High-Performance Anodes.” Energy Environ. Sci., 11, 2310 (2018).

12. CNRS News https://news.cnrs.fr/articles/a-battery-revolution-in-motion.

13. K. Smith, J. Treacher, D. Ledwoch, P. Adamson, and E. Kendrick, "Novel High Energy Density Sodium Layered Oxide Cathode Materials: From Material to Cells." ECS Trans., 75, 13 (2017).

14. R. Dugas, B. Zhang, P. Rozier, and J. M. Tarascon, "Optimization of Na-Ion Battery Systems Based on Polyanionic or Layered Positive Electrodes and Carbon Anodes." J. Electrochem. Soc., 163, A867 (2016). 
15. G. Yan, M. Sathiya, G. Rousse, Q. Jacquet, M. Deschamps, R. David, B. Mirvaux, J. W. Freeland, and J-M. Tarascon, "Higher Energy and Safer Sodium Ion Batteries via an in situ Electrochemically Made Disordered New $\mathrm{Na}_{3} \mathrm{~V}_{2}\left(\mathrm{PO}_{4}\right)_{2} \mathrm{~F}_{3}$ Material.' Nat. Commun., Submitted.

16. C. Delmas, C. Fouassier, and P. Hagenmuller, "Structural Classification and Properties of the Layered Oxides." Phys. BC, 99, 81 (1980).

17. M. Sathiya, K. Hemalatha, K. Ramesha, J.-M. Tarascon, and A. S. Prakash, "Synthesis, Structure, and Electrochemical Properties of the Layered Sodium Insertion Cathode Material: $\mathrm{NaNi}_{1 / 3} \mathrm{Mn}_{1 / 3} \mathrm{Co}_{1 / 3} \mathrm{O}_{2}$ ". Chem. Mater., 24, 1846 (2012).

18. L. Viciu, J. W. G. Bos, H. W. Zandbergen, Q. Huang, M. L. Foo, S. Ishiwata, A. P. Ramirez, M. Lee, N. P. Ong, and R. J. Cava, "Crystal Structure and Elementary Properties of $\mathrm{Na}_{\mathrm{x}} \mathrm{CoO}_{2}(\mathrm{x}=0.32,0.51,0.6,0.75$, and 0.92) in the Three-Layer $\mathrm{NaCoO}_{2}$ Family." Phys. Rev. B, 73, (2006).

19. M. Bianchini, N. Brisset, F. Fauth, F. Weill, E. Elkaim, E. Suard, C. Masquelier, and L. Croguennec, " $\mathrm{Na}_{3} \mathrm{~V}_{2}\left(\mathrm{PO}_{4}\right)_{2} \mathrm{~F}_{3}$ Revisited: A High-Resolution Diffraction Study." Chem. Mater, 26, 4238 (2014).

20. U. Maitra, R. A. House, J. W. Somerville, N. Tapia-Ruiz, J. G. Lozano, N. Guerrini, R. Hao, K. Luo, L. Jin, M. A. Pérez-Osorio, F. Massel, D. M. Pickup, S. Ramos, X. Lu, D. E. McNally, A. V. Chadwick, F. Giustino, T. Schmitt, L. C. Duda, M. R. Roberts, and P. G. Bruce, "Oxygen Redox Chemistry without Excess Alkali-Metal Ions in $\mathrm{Na}_{2 / 3}\left[\mathrm{Mg}_{0.28} \mathrm{Mn}_{0.72}\right] \mathrm{O}_{2}$." Nat. Chem., 10, 288 (2018).

21. M. Sathiya, J. Thomas, D. Batuk, V. Pimenta, R. Gopalan, and J-M. Tarascon, "Dua Stabilization and Sacrificial Effect of $\mathrm{Na}_{2} \mathrm{CO}_{3}$ for Increasing Capacities of Na-Ion Cells Based on P2-Na $\mathrm{MO}_{2}$ Electrodes." Chem. Mater., 29, 5948 (2017).

22. X. Ma, H. Chen, and G. Ceder, "Electrochemical properties of monoclinic $\mathrm{NaMnO}_{2}$." J. Electrochem. Soc., 158 (12), A1307 (2011).

23. J. M. Paulsen and J. R. Dahn, "Studies of the Layered Manganese Bronzes, $\mathrm{Na}_{2 / 3}\left[\mathrm{Mn}_{1-\mathrm{x}} \mathrm{M}_{\mathrm{x}}\right] \mathrm{O}_{2}$ with $\mathrm{M}=\mathrm{Co}, \mathrm{Ni}, \mathrm{Li}$, and $\mathrm{Li}_{2 / 3}\left[\mathrm{Mn}_{1-\mathrm{x}} \mathrm{M}_{\mathrm{x}}\right] \mathrm{O}_{2}$ Prepared by IonExchange" Solid State Ion., 126, 3 (1999).

24. L. Zhang, J-M. Tarascon, M. T. Sougrati, G. Rousse, and G. Chen, "Influence of relative humidity on the structure and electrochemical performance of sustainable LiFeSO4F electrodes for Li-ion batteries." J. Mater. Chem. A., 3, 16988 (2015).

25. N. Yabuuchi, M. Kajiyama, J. Iwatate, H. Nishikawa, S. Hitomi, R. Okuyama, R. Usui, Y. Yamada, and S. Komaba, "P2-Type $\mathrm{Na}_{x}\left[\mathrm{Fe}_{1 / 2} \mathrm{Mn}_{1 / 2}\right] \mathrm{O}_{2}$ Made from EarthAbundant Elements for Rechargeable Na Batteries." Nat. Mater., 11, 512 (2012).

26. E. Talaie, S. Y. Kim, N. Chen, and L. F. Nazar, "Structural Evolution and Redox Processes Involved in the Electrochemical Cycling of $\mathrm{P} 2-\mathrm{Na}_{0.67}\left[\mathrm{Mn}_{0.66} \mathrm{Fe}_{0.2} \mathrm{Cu}_{0.14}\right] \mathrm{O}_{2}$." Chem. Mater, 29, 6684 (2017).

27. M. Sathiya, Q. Jacquet, M.-L. Doublet, O. M. Karakulina, J. Hadermann, and J.-M. Tarascon, "A Chemical Approach to Raise Cell Voltage and Suppress Phase Transition in O3 Sodium Layered Oxide Electrodes." Adv. Energy Mater., 8, 1702599 (2018)

28. P.-F. Wang H.-R. Yao, X. Y. Liu, J.-N. Zhang, L. Gu, X.-Q. Yu, Y.-X. Yin, and Y.-G. Guo, "Ti-Substituted $\mathrm{NaNi}_{0.5} \mathrm{Mn}_{0.5-\mathrm{x}} \mathrm{Ti}_{\mathrm{x}} \mathrm{O}_{2}$ Cathodes with Reversible O3-P3
Phase Transition for High-Performance Sodium-Ion Batteries." Adv. Mater, 29, 1700210 (2017)

29. X. Li, Y. Wang, D. Wu, L. Liu, S.-H. Bo, and G. Ceder, "Jahn-Teller Assisted Na Diffusion for High Performance Na Ion Batteries." Chem. Mater., 28, 6575 (2016).

30. B. Zhang, R. Dugas, G. Rousse, P. Rozier, A. M. Abakumov, and J.-M. Tarascon, "Insertion Compounds and Composites Made by Ball Milling for Advanced SodiumIon Batteries." Nat. Commun., 7, 10308 (2016)

31. G. Singh, B. Acebedo, M. C. Cabanas, D. Shanmukaraj, M. Armand, and T. Rojo, "An Approach to Overcome First Cycle Irreversible Capacity in $\mathrm{P} 2-\mathrm{Na}_{2 / 3}\left[\mathrm{Fe}_{1 / 2} \mathrm{Mn}_{1 / 2}\right] \mathrm{O}_{2}$." Electrochem. Commun., 37, 61 (2013).

32. A. Manthiram, J. C. Knight, S.-T. Myung, S.-M. Oh, and Y.-K. Sun, "Nickel-Rich and Lithium-Rich Layered Oxide Cathodes: Progress and Perspectives." Adv. Energy Mater, 6, 1501010 (2016).

33. P. Rozier and J. M. Tarascon, "Review-Li-Rich Layered Oxide Cathodes for NextGeneration Li-Ion Batteries: Chances and Challenges." J. Electrochem. Soc., 162, A2490 (2015).

34. Xue Bai, M. Sathiya, B. Mendoza-Sánchez, A. Iadecola, J. Vergnet, R. Dedryvère, M. Saubanère, A. M. Abakumov, P. Rozier, and J.-M. Tarascon, "Anionic Redox Activity in a Newly Zn-Doped Sodium Layered Oxide P2-Na $2 / 3 \mathrm{Mn}_{1-\mathrm{y}} \mathrm{Zn}_{\mathrm{y}} \mathrm{O}_{2}(0<$ y < 0.23)." Adv. Energy Mater., 1802379.

35. G. Assat, D. Foix, C. Delacourt, A. Iadecola, R. Dedryvère, and J.-M. Tarascon, "Fundamental Interplay between Anionic/Cationic Redox Governing the Kinetics and Thermodynamics of Lithium-Rich Cathodes." Nat. Commun., 8, (2017)

36. C. Delmas, J. Braconnier, C. Fouassier, and P. Hagenmuller, "Electrochemical Intercalation of Sodium in $\mathrm{Na}_{\mathrm{x}} \mathrm{CoO}_{2}$ Bronzes." Solid State Ion., 3-4, 165 (1981).

37. M. D. Radin and A. Van der Ven, "Stability of Prismatic and Octahedral Coordination in Layered Oxides and Sulfides Intercalated with Alkali and Alkaline-Earth Metals." Chem. Mater, 28, 7898 (2016).

38. J. Vinckevičiuūte, M. D. Radin, and A. Van der Ven, "Stacking-Sequence Changes and Na Ordering in Layered Intercalation Materials." Chem. Mater, 28, 8640 (2016).

39. B. Mortemard de Boisse Cheng, D. Carlier, M. Guignard, C.-J. Pan, S. Bordère, D. Filimonov, C. Drathen, E. Suard, and B.-J. Hwang, "O3- $\mathrm{Na}_{\mathrm{x}} \mathrm{Mn}_{1 / 3} \mathrm{Fe}_{2 / 3} \mathrm{O}_{2}$ as a Positive Electrode Material for Na-Ion Batteries: Structural Evolutions and Redox Mechanisms upon $\mathrm{Na}^{+}$(de)Intercalation." J. Mater. Chem. A, 3, 10976 (2015).

40. L. Zheng and M. N. Obrovac, "Investigation of O3-Type $\mathrm{Na}_{0.9} \mathrm{Ni}_{0.45} \mathrm{Mn}_{\mathrm{x}} \mathrm{Ti}_{0.55-\mathrm{x}} \mathrm{O}_{2}(0$ $\leq \mathrm{x} \leq 0.55)$ as Positive Electrode Materials for Sodium-Ion Batteries." Electrochimica Acta, 233, 284 (2017).

41. S. Komaba, N. Yabuuchi, T. Nakayama, A. Ogata, T. Ishikawa, and I. Nakai, "Study on the Reversible Electrode Reaction of $\mathrm{Na}_{1-\mathrm{x}} \mathrm{Ni}_{0.5} \mathrm{Mn}_{0.5} \mathrm{O}_{2}$ for a Rechargeable SodiumIon Battery." Inorg. Chem., 51, 6211 (2012).

42. Q. Wang, S. Mariyappan, J.-M. Tarascon et al., In preparation. 